54

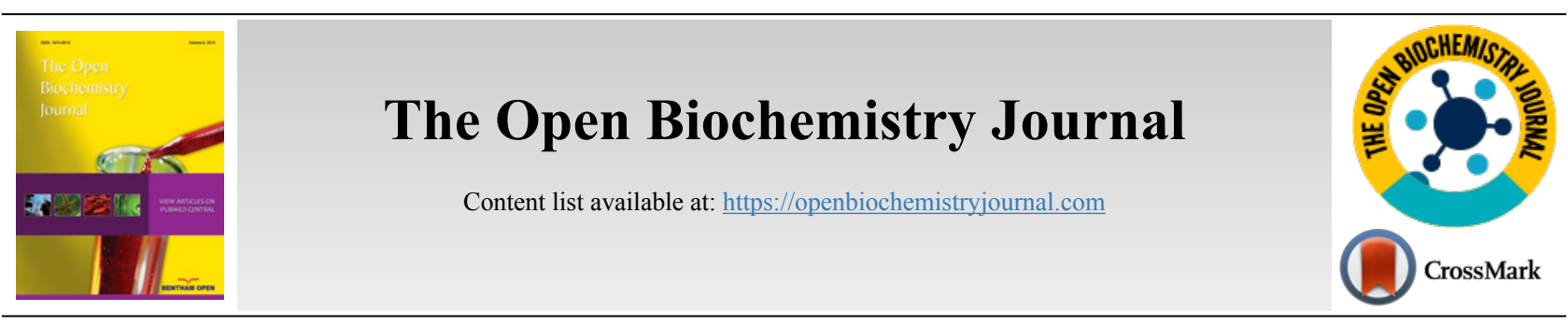

RESEARCH ARTICLE

\title{
Purification and Biochemical Characterization of Cysteine Protease from Baby Kiwi (Actinidia arguta)
}

Sayaka Miyazaki-Katamura ${ }^{1,2}$, Mio Yoneta-Wada ${ }^{1,3}$, Miyuki Kozuka ${ }^{4,5}$, Tomohisa Sakaue ${ }^{6}$, Takuya Yamane ${ }^{5,7}$, Junko Suzuki ${ }^{1}$, Yoshihito Arakawa ${ }^{1,3}$ and Iwao Ohkubo ${ }^{1,8, *}$

'Department of Nutrition, School of Nursing and Nutrition, Tenshi College, Sapporo 065-0013, Japan

${ }^{2}$ Department of Food Science and Human Wellness, College of Agriculture, Food and Environmental Sciences, Rakuno Gakuen University, Ebetsu 069-0836, Japan

${ }^{3}$ Department of Nutrition, School of Nursing and Nutrition, Sapporo University of Health Sciences, Sapporo 077-0894, Japan

${ }^{4}$ Department of Health and Nutrition, Faculty of Human Science, Hokkaido Bunkyo University, Eniwa 061-1449, Japan

${ }^{5}$ Graduate School of Pharmaceutical Sciences, Hokkaido University, Sapporo 060-0812, Japan

${ }^{6}$ Department of Biochemistry and Molecular Genetics, Ehime University Graduate School of Medicine, Toon 791-0295, Japan

${ }^{7}$ Center for Research and Development Bioresources, Research Organization for University-Community Collaborations, Osaka Prefecture University, Sakai 599-8570, Japan

${ }^{8}$ Department of Pediatrics, Mikasa City Hospital, Mikasa 068-2156, Japan

\section{Abstract:}

Background:

It has recently been reported that the fruit, stems and leaves of Actinidia arguta have various potential health effects including an antioxidant effect, anticancer effect, anti-allergic effect and $\alpha$-glucosidase inhibitory effect. However, little is known about the biochemical properties of cysteine protease in the fruit juice of $A$. arguta.

\section{Methods:}

Ion exchange chromatography to purify the cysteine protease from the fruit juice of $A$. arguta, and some synthetic substrates to determinate the enzyme activity were used.

\section{Results:}

Cysteine protease was purified to homogeneity from $A$. arguta fruit juice by ion exchange chromatography. The molecular weight of the purified enzyme was calculated to be approximately 25,500 by SDS-PAGE in the presence of $\beta$-ME. The enzyme rapidly hydrolyzed the substrate Z-LeuArg-MCA and moderately hydrolyzed other substrates including Boc-Val-Leu-Lys-MCA, Z-Val-Val-Arg-MCA and Z-Phe-Arg-MCA. Kinetic parameters for these four substrates were determined. The $K_{\mathrm{m}}, V_{\mathrm{max}}, K_{\text {cat }}$ and $K_{\text {cat }} / K_{\mathrm{m}}$ values for Z-Leu-Arg-MCA, the most preferentially cleaved by the enzyme, were $100 \mu \mathrm{M}, 63.8 \mu \mathrm{moles} / \mathrm{mg} / \mathrm{min}, 27.26 \mathrm{sec}^{-1}$ and $0.2726 \mathrm{sec}^{-1} \mu \mathrm{M}^{-1}$, respectively. Furthermore, the activity of the enzyme was strongly inhibited by inhibitors including antipain, leupeptin, E-64, E-64c, kinin-free-LMW kininogen and cystatin C. Those biochemical data indicated that the enzyme was a cysteine protease. The amino acid sequence of the first 21 residues of cysteine protease purified from Actinidia arguta was Val $^{1}$-Leu-Pro-Asp-Tyr ${ }^{5}$-Val-Asp-Trp-Arg-Ser ${ }^{10}$-Ala-Gly-Ala-Val-Val ${ }^{15}$-Asp-Ile-Lys-Ser-Qln ${ }^{20}$-Gly. This sequence showed high homology to the sequences of actinidin from Acinidia deliciosa $(95.0 \%)$ and actinidin from Actinidia eriantha (90\%). These three cysteine proteases were thought to be common allied species.

\section{Conclusion:}

The biochemical properties of the enzyme purified from $A$. arguta fruit juice were determined. These basic data are expected to contribute to the maintenance and improvement of human health as well as to the promotion of protein digestion and absorption through its proteolytic functions.

Keywords: Actinidia arguta, Cysteine protease, Purification, Biochemichal properties, Allied species, Chromatography.

\begin{tabular}{|l|l|l|l|}
\hline Article History & Received: April 30, 2019 & Revised: July 31, 2019 & Accepted: August 02, 2019 \\
\hline
\end{tabular}




\section{INTRODUCTION}

Actinidia arguta Planch., known as baby kiwi, hardy kiwi or arctic kiwi in English and Sarunashi in Japanese, is a vine tree that is natively widespread in Northern Asia including Russian Siberia, Northern China, Korea, Japan [1] and also in southern Asia including Vietnam, Peninsular Malaysia and New Guinea [2].

A. arguta is an edible small fruit-producing perennial vine belonging to the Actinidia genus in the Actinidiaceae family and produces a small fruit that is rich in anthocyanins, catechins, chlorophyll, $\beta$-carotene, vitamin $\mathrm{C}$, lutein, several minerals (potassium, calcium and zinc) and other polyphenols [3].

It has recently been reported that the fruit, stems and leaves of $A$. arguta have various potential health effects including an antioxidant effect [4 - 6], antiproliferative effect [4], anticancer property [7], antimutagenesis effect [8], anti-allergic effect [9] and $\alpha$-glucosidase inhibitory effect $[9,10]$. Thus, the properties of $A$. arguta are thought to be beneficial for human health.

Furthermore, the proteolytic properties of actinidin, bromelain, ficin and papain, which have been identified in kiwifruit [11, 12], pineapple [13], figs [14] and papaya [15], have been extensively studied as good meat tenderizers [12 16]. All of these proteases have been confirmed to be cysteine proteases [EC 3.4.22.-]. They are categorized into clan CA and family C1 (papain family) (see Merops: http://www.merops. ac.uk).

The cDNA structure and amino acid sequence derived from cDNA structures of cysteine protease from A. arguta have been reported [17], and the crystallographical structure of the enzyme has also been determined [18]. However, little is known about the biochemical and physiological properties of cysteine protease in the fruit juice of A. arguta [19].

In this paper, we describe a simple procedure for the isolation of cysteine protease from baby kiwi (A. arguta) fruit juice and we also report the biochemical and physiological properties including molecular weight, kinetic parameters and $N$-terminal amino acid sequence.

\section{MATERIALS AND METHODS}

\subsection{Materials}

Frozen fruit samples of baby kiwi (A. arguta) harvested in the vicinity of Sapporo City (Hokkaido, Japan) that had been ripened for 2 days at room temperature were stored at $-30^{\circ} \mathrm{C}$ until use.

Silver vine (Actinidia polygama) was also harvested in the vicinity of Kushiro City (Hokkaido, Japan), and both green kiwi (Actinidia deliciosa cv. Hayward) and gold kiwi (Actinidia chinensis cv. Hort16A) fruits were purchased from a city market.

Protease inhibitors including E-64, and antipain and fluoro-

* Address correspondence to this author at the Department of Nutrition, School of Nursing and Nutrition, Tenshi College, Sapporo 065-0013, Japan; Tel: +81 11741 1051; Fax: +81 11741 1077; E-mail: ohkubo@tenshi.ac.jp genic peptide substrates including Z-Leu-Arg-MCA and ZPhe-Arg-MCA were purchased from Peptide Institute (Osaka, Japan). Bio-Safe Coomassie G-250, Quick start ${ }^{\mathrm{TM}}$ Bradford 1x dye solution, Mini-Protean TGX precast gels (any $\mathrm{kD}$ ) and UNOspheare Q were obtained from Bio-Rad Laboratories (Hercules, CA, USA).

All other chemicals were of analytical grade.

\subsection{Assay of Cysteine Protease Activity}

Enzyme activity was measured by fluorometrical number (excitation, $360 \mathrm{~nm}$; emission, $460 \mathrm{~nm}$ ) of liberation of AMC at $37^{\circ} \mathrm{C}$ for $10 \mathrm{~min}$ in a mixture containing $10 \mu \mathrm{l}$ of $10 \mathrm{mM}$ of the substrate Z-Leu-Arg-MCA, $100 \mu 1$ of $0.5 \mathrm{M} \mathrm{Na-phosphate}$ buffer, $\mathrm{pH} 7.0,10 \sim 20 \mu \mathrm{l}$ of diluted enzyme solution and Mili Q water $(18 \mathrm{~m} \Omega)$ in a total volume of $1 \mathrm{ml}$. Liberated AMC was determined with the VersaFluor Flurometer system (Bio-Rad, Hercules, CA, USA). One unit of activity was defined as the amount of enzyme that hydrolyzes $1 \mu$ mole of the substrate per minute.

\subsection{Protein Quantitation}

To determined protein concentrations, absorbance at 280 $\mathrm{nm}$ and/or a Protein assay kit (Bradford's method [20]) (BioRad Laboratories, Hercules, CA, USA) were used. The samples were analyzed in a Shimazu UV-1850 UV-VIS spectrophotometer (Kyoto, Japan).

\subsection{Polyacrylamide Gel Electrophoresis and Molecular Weight Determination}

Slab gel electrophoresis was carried out on polyacrylamide gels (Mini-protean TGX precast gels (any $\mathrm{kD}$ or $4 \sim 20 \%$ )) obtained from Bio-Rad Laboratories (Bio-Rad, Hercules, CA, USA) by the method of Laemmli [21]. Proteins in the gel were stained with Bio-Safe Coomassie Brilliant Blue G-250 (BioRad Laboratories, Hercules, CA, USA).

\subsection{Molecular Weight Determination}

The molecular weight of the enzyme was determined by SDS-PAGE. As the standard protein, precision plus protein ${ }^{\mathrm{TM}}$ prestained standard (Mr $10 \sim 250 \mathrm{kDa}$ ) obtained from Bio-Rad Laboratories (Hercules, CA, USA) was used.

\subsection{Purification of Cysteine Protease from Actinidia Arguta}

\section{Step 1. Extraction of Protease from Baby Kiwi Fruits and Dialysis}

Baby kiwi fruits $(\sim 250 \mathrm{~g})$ were chopped into small pieces after peeling off the skin, and one volume of cold $40 \mathrm{mM}$ Tris- $\mathrm{HCl}$ buffer, $\mathrm{pH} 8.0$, containing $10 \mathrm{mM} \beta$-ME was added. The solution was centrifuged at $12,500 \mathrm{x}$ g for $45 \mathrm{~min}$, and then the supernatant obtained was dialyzed overnight against 20 $\mathrm{mM}$ Tris- $\mathrm{HCl}$ buffer, $\mathrm{pH} 8.0$, containing $10 \mathrm{mM} \beta$-ME. To remove the precipitate, the supernatant was centrifuged again at $12,500 \mathrm{x}$ g for $45 \mathrm{~min}$. 


\section{Step 2. UNO sphere Q Column Chromatography}

The dialysate was applied at a flow rate of $1.0 \mathrm{ml} / \mathrm{min}$ to a UNOsphere Q column (bed volume, $20 \mathrm{ml}$ ) pre-equilibrated with $20 \mathrm{mM}$ Tris- $\mathrm{HCl}$ buffer, $\mathrm{pH} 8.0$, containing $10 \mathrm{mM} \beta$-ME. The column was washed extensively with the same equilibration buffer, and then a linear gradient was formed with 100 $\mathrm{ml}$ of the same buffer and $100 \mathrm{ml}$ of the same buffer containing $0.45 \mathrm{M} \mathrm{NaCl}$. Fractions containing cysteine protease activity were collected. The solution was immediately used in subsequent experiments.

\subsubsection{Kinetic Analysis}

The concentration of an inhibitor that gave $50 \%$ inhibition $\left(\mathrm{IC}_{50}\right)$ was determined through a series of assays with a fixed substrate concentration of $100 \mu \mathrm{M}$ but with various inhibitor concentrations.

To determine $K \mathrm{~m}$ and $V \max$ values, double-reciprocal plots (Lineweaver-Burk plots) were utilized.

\subsubsection{N-Terminal Amino Acid Sequencing}

Purified cysteine protease ( $20 \mu \mathrm{g}: \sim 0.77 \mathrm{pmol})$ was subjected to electrophoresis in $15 \%$ SDS-PAGE and transferred to a polyvinylidene difluoride (PVDF) membrane (Bio-Rad Laboratories). The membrane was stained with $0.1 \%$ Coomassie Brilliant Blue R-250 in 10\% methanol-7\% acetic acid. The protein band to be examined was cut out, washed with 50\% methanol, and then sequenced by automated Edman degradation using an Applied Biosystems Model 492 cLC (ABI, Foster City, CA, USA). A protein sequencer equipped with an online phenylthiohydantoin analyzer (ABI 120A analyzer, Foster City, CA, USA) was used.

\section{RESULTS AND DISCUSSION}

\subsection{Activation of Cysteine Protease by $\beta$-ME}

The enzyme from A. arguta fruit juice in the absence of $\beta$ ME showed very low activity using the substrate Z-Leu-ArgMCA. However, in the presence of $5 \sim 15 \mathrm{mM} \beta-\mathrm{ME}$, the enzyme showed about 160 220-fold higher activity than the activity in the absence of $\beta$-ME (Fig. 1). These results indicated that the enzyme exists as a precursor form in the fruit juice and that the enzyme is activated by sulfhydryl reagents such as $\beta$ $\mathrm{ME}$ and cysteine [22,23]. Accordingly, $10 \mathrm{mM} \beta$-ME was added to the assay mixture and purification buffer (Tris- $\mathrm{HCl}$ buffer, $\mathrm{pH}$ 8.0) in subsequent experiments.

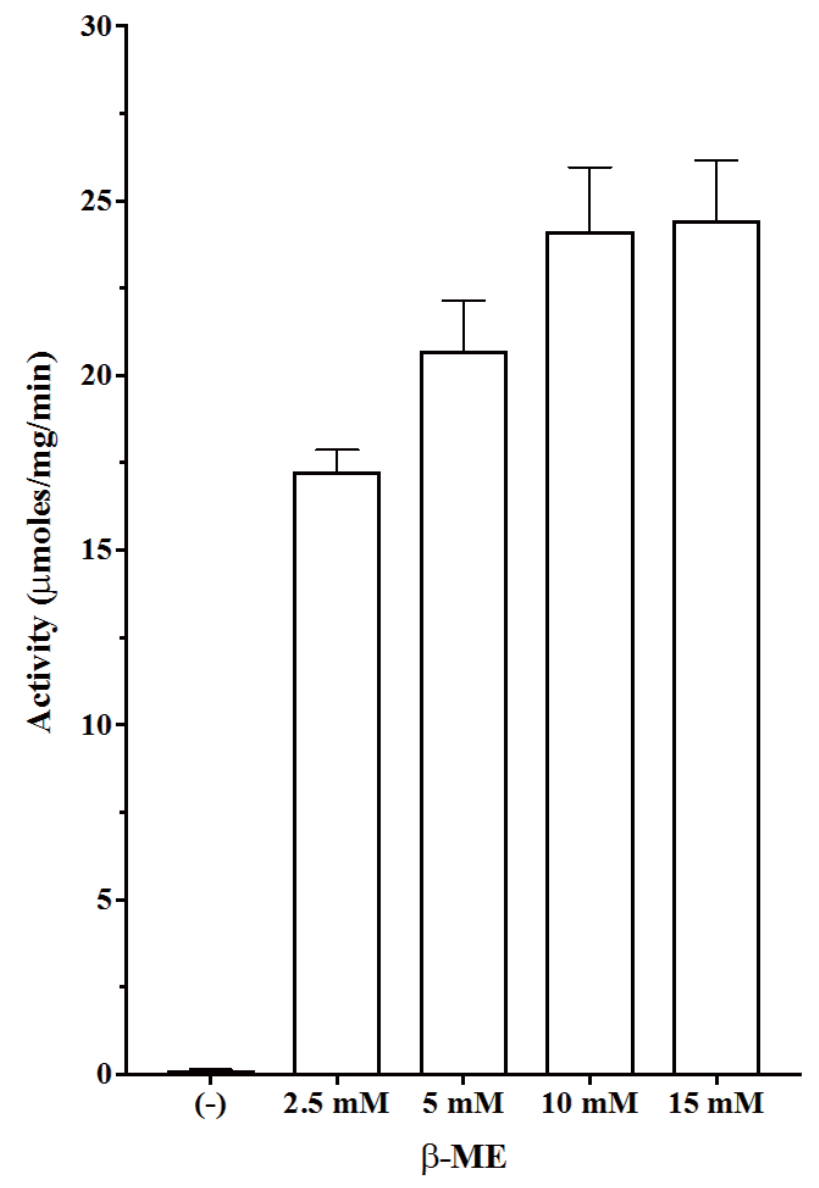

Fig. (1). Activation of cysteine protease by $\beta$-ME.

Each value is the mean $\pm \mathrm{SE}$ from triplicate experiments. 
3.2. Comparison of Specific Activities Among A. arguta, A. delisiosa, $A$. chinensis and $A$. polygama

The enzyme activities of fruit juices extracted from $A$. arguta, A. delisiosa, A. chinensis and A. polygama were determined in the presence of $10 \mathrm{mM} \beta$-ME using the substrate Z-Leu-Arg-MCA. The activity of $A$. arguta fruit juice showed the highest activity (Table $\mathbf{1}$ ). The order of their relative activities was $A$. arguta $(16.97 \mu \mathrm{moles} / \mathrm{mg} / \mathrm{min}, 100 \%)>A$. delisiosa $(4.70 \mu \mathrm{moles} / \mathrm{mg} / \mathrm{min}, 45.4 \%)>$ A. polygama $(0.83$ $\mu \mathrm{moles} / \mathrm{mg} / \mathrm{min}, 4.89 \%)>A$. chinensis $(0.83 \mu \mathrm{moles} / \mathrm{mg} / \mathrm{min}$, $0.0015 \%)$

\subsection{Enzyme Purification}

Cysteine protease from $A$. arguta was purified by chromatography on a UNOsphere Q column (Fig. 2). Table 2 shows a typical procedure for purification of the enzyme. Finally, the cysteine protease from $A$. arguta was purified approximately 2.12 -fold with a $62.1 \%$ yield over dialyzed $A$. arguta homogenate. The enzyme in the final step gave a single band on SDS-PAGE in the presence of $\beta$-ME (Fig. 2). The overall yield of cysteine protease from $100 \mathrm{~g}$ of $A$. arguta was approximately $13.3 \mathrm{mg}$.

Table 1. Comparison of specific activities among $A$. arguta, $A$. deliciosa, $A$. chinensis and $A$. polygama.

\begin{tabular}{|c|c|c|}
\hline & Specific Activity ( $\boldsymbol{\mu m o l e s / m g / m i n )}$ & Relative Activity (\%) \\
\hline Actinidia arguta & 16.97 & 100.0 \\
\hline Actinidia deliciosa & 7.70 & 45.4 \\
\hline Actinidia chinensis & 0.025 & 0.015 \\
\hline Actinidia polygama & 0.83 & 4.89 \\
\hline
\end{tabular}

Table 2. Purification of cysteine protease from $A$. arguta.

\begin{tabular}{|c|c|c|c|c|c|}
\hline Step & Total Protein (mg) & Total Activity (units) & Specific Activity ( $\boldsymbol{\mu m o l e s / m g / m i n ) ~}$ & Purification (-fold) & Yield (\%) \\
\hline Dialysis & 70.35 & 1980 & 28.15 & 1 & 100 \\
\hline UNOsphere Q & 20.59 & 1228.8 & 59.68 & 62.1 \\
\hline
\end{tabular}

*Protein concentration was measured by Bradford's method using bovine serum albumin as a standard.

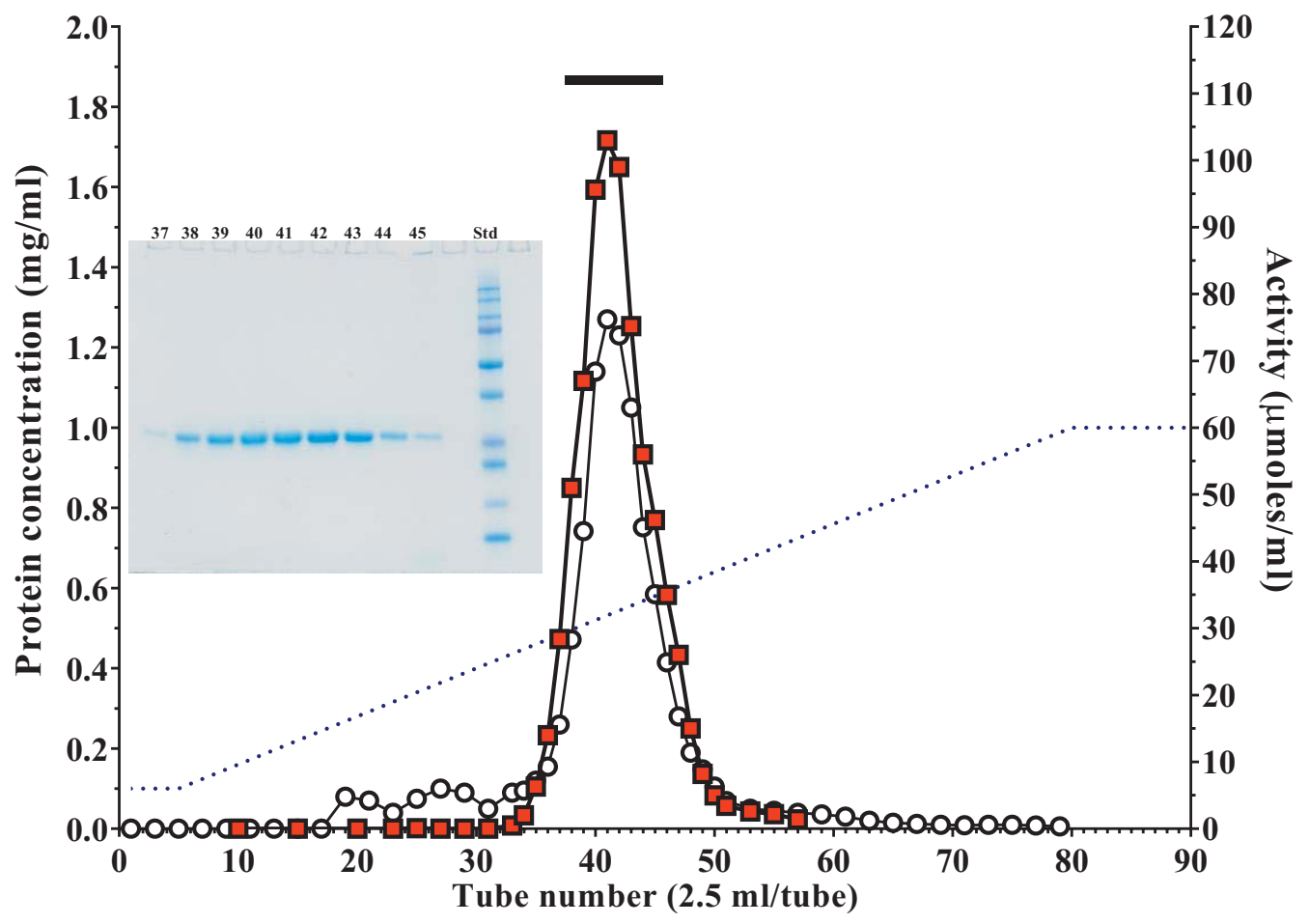

Fig. (2). Purification of cysteine protease from Actinidia arguta using UNOsphere Q column chromatography.

Fractions containing cysteine protease activity were collected. The bar indicates the fractions that were pooled. Protein concentration (mg/ml) $(\circ)$, cysteine protease activity ( $\mathbf{})$ and sodium chloride gradient (--). Insert: SDS-PAGE of fractions containing the enzyme activity. $3 \mu 1$ of each aliquot (fraction numbers 37 to 45 ) was subjected to SDS-PAGE. 


\subsection{Biochemical Properties of the Purified Enzyme}

\subsubsection{Molecular Weight}

Cysteine protease from A. arguta fruit juice was purified to homogeneity, and the molecular weight of the enzyme was calculated to be approximately 25,500 on SDS-PAGE (Fig. 3). The value of its molecular weight was close to those of enzymes from other plants including actinidin $(M r 23,000$ 24,000) $[18,24,25]$, papain $(M r 23,400)$ [26] and ficain (ficin) (Mr 23,400) [27].

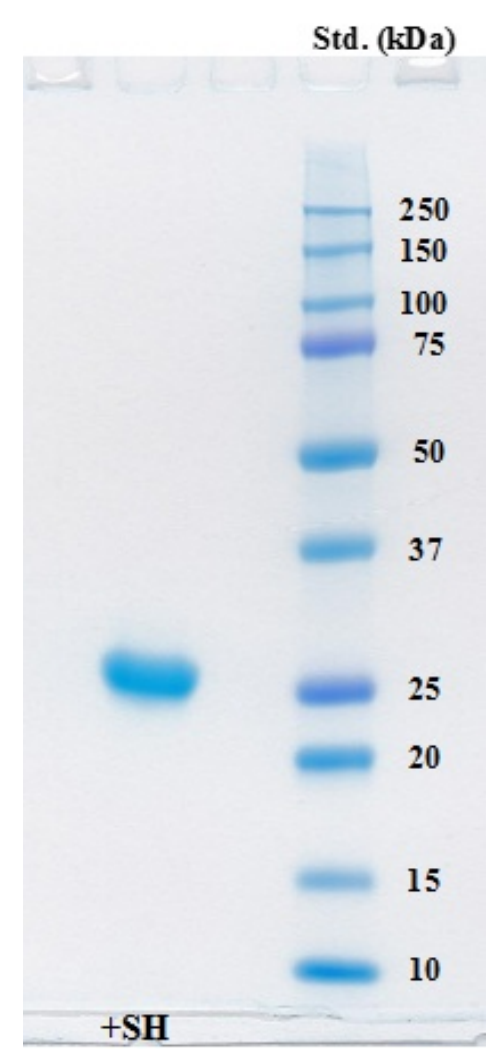

Fig. (3). Polyacrylamide gel electrophoresis of cysteine protease from Actinidia arguta.

Electrophoresis of the purified enzyme was carried out on a Miniprotean TGX precast gel (any $\mathrm{kD}$ ) in the presence of SDS and the gel was stained with Coomassie Brilliant Blue G-250. Lane 1 contained 5 $\mu \mathrm{g}$ of the purified protein in the presence of $\beta$-ME. Precision Plus protein standards (Bio-Rad) were also used for estimation of molecular weight.

\subsubsection{Substrate Specificity}

As shown in Fig. (4), cysteine protease from Actinidia arguta exhibited high activity toward the synthetic substrate ZLeu-Arg-MCA and moderate activity toward Z-Val-Leu-LysMCA, Z-Val-Val-Arg-MCA, Z-Phe-Arg-MCA and Pro-PheArg-MCA. Furthermore, the enzyme very weakly hydrolyzed the substrates Z-Gly-Pro-Arg-MCA, Boc-Val-Pro-Arg-MCA and Z-Arg-Arg-MCA. It did not hydrolyze substrates for cathepsin H (Arg-MCA), elastase (Suc-Ala-Ala-Ala-MCA) and tripeptidyl peptidase II (Ala-Ala-Phe-MCA).

Our results indicated that the enzyme preferentially cleaves the peptide bond between $\mathrm{P}^{1}$ (Arg or Lys) and $\mathrm{P}^{\prime 1}$ positions in the presence of a hydrophobic amino acid such as Leu, Val and Phe at the $\mathrm{P}^{2}$ position.

\subsubsection{Optimal pH, pH Stability, Optimal Temperature and Thermo-stability}

Cysteine protease activity was assayed in the $\mathrm{pH}$ range of 3.0 to 8.0 using citrate and sodium-phosphate buffers. The activity of cysteine protease toward the substrate Z-Leu-ArgMCA was optimal at pH 6.5 - 7.5 when sodium phosphate buffer was used (Fig. 5A).

To examine the effect of $\mathrm{pH}$ on stability, the enzyme was incubated at various $\mathrm{pH}$ values (GTA buffer: 3.5 to 10.0 ) for 24 $\mathrm{hr}$ at $4{ }^{\circ} \mathrm{C}$. The enzyme was stable over a wide $\mathrm{pH}$ range from 4.0 to 8.5 (Fig. 5B).

The temperature for the optimal hydrolysis of the above substrate was approximately $50^{\circ} \mathrm{C}$ (Fig. 5C).

The enzyme activity was thermo-stable up to $45^{\circ} \mathrm{C}$ for 10 min of incubation (Fig. 5D).

In $20 \mathrm{mM}$ sodium phosphate buffer, $\mathrm{pH} 7.0$, the enzyme was stable for at least 7 days at $4{ }^{\circ} \mathrm{C}$ and three months at $-30^{\circ} \mathrm{C}$.

\subsubsection{Kinetic Parameters}

The $K_{\mathrm{m}}, V_{\text {max }}, K_{\text {cat }}$ and $K_{\text {cat }} / K_{\mathrm{m}}$ values of the purified enzyme for four substrates at optimal $\mathrm{pH}(\mathrm{pH}$ 7.0) were determined (Table 2). The $K_{\mathrm{m}}, V_{\max }, K_{\text {cat }}$ and $K_{\text {cat }} / K_{\mathrm{m}}$ values for Z-Leu-ArgMCA, which was most preferentially cleaved by the enzyme, were $100 \mu \mathrm{M}, 63.8 \mu$ moles $/ \mathrm{mg} / \mathrm{min}, 27.12 \mathrm{sec}^{-1}$ and 0.2712 $\sec ^{-1} \mu \mathrm{M}^{-1}$, respectively. The relative order of Kcat was Z-LeuArg-MCA $>$ Boc-Val-Leu-Lys-MCA $\geq Z$ Z-Val-Val-Arg-MCA $>$ Z-Phe-Arg-MCA and the relative order of $K_{\text {cat }} / K_{\mathrm{m}}$ was Z-LeuArg-MCA $>$ Boc-Val-Leu-Lys-MCA $>$ Z-Val-Val-Arg-MCA $=$ $\mathrm{Z}-\mathrm{Phe}-\mathrm{Arg}-\mathrm{MCA}$. These results indicated that Z-Leu-ArgMCA is the best substrate among the four substrates and coincided with the results shown in Fig. (4).

\subsubsection{Inhibition of Enzyme Activity by Standard Protease Inhibitors}

Various protease inhibitors against cysteine protease from A. arguta were examined (Fig. 6). Cysteine protease activity was strongly inhibited by antipain, leupeptin, E-64 and E-64c, and Z-LLL-H (aldehyde) and was moderately inhibited by pepstatin A. However, the enzyme activity was not inhibited by EDTA, AEBSF, CA-074 and leuhistin. Accordingly, the enzyme from $A$. arguta was confirmed to belong to the cysteine protease family. 


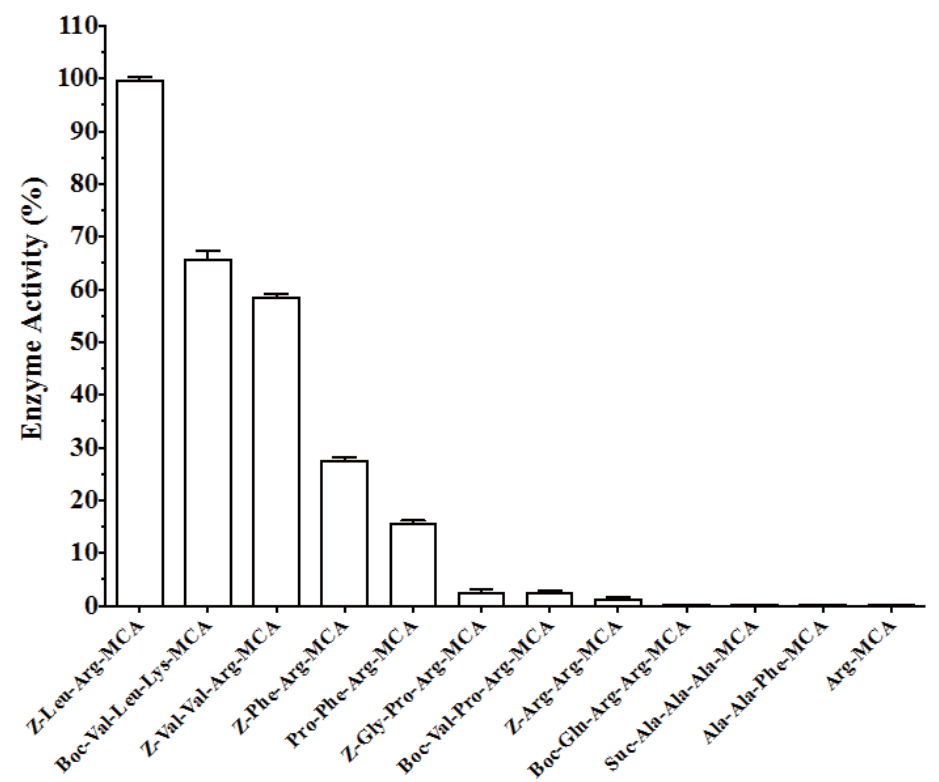

Fig. (4). Substrate specificity of purified cysteine protease from Actinidia arguta.

Each assay was carried out at $37^{\circ} \mathrm{C}$ for $10 \mathrm{~min}$ in $50 \mathrm{mM}$ sodium phosphate buffer, $\mathrm{pH} 7.0$, in the presence of the purified enzyme $(0.5 \mu \mathrm{g})$ and 100 $\mu \mathrm{M}$ of a substrate. Each value is the mean $\pm \mathrm{SE}$ from triplicate experiments.
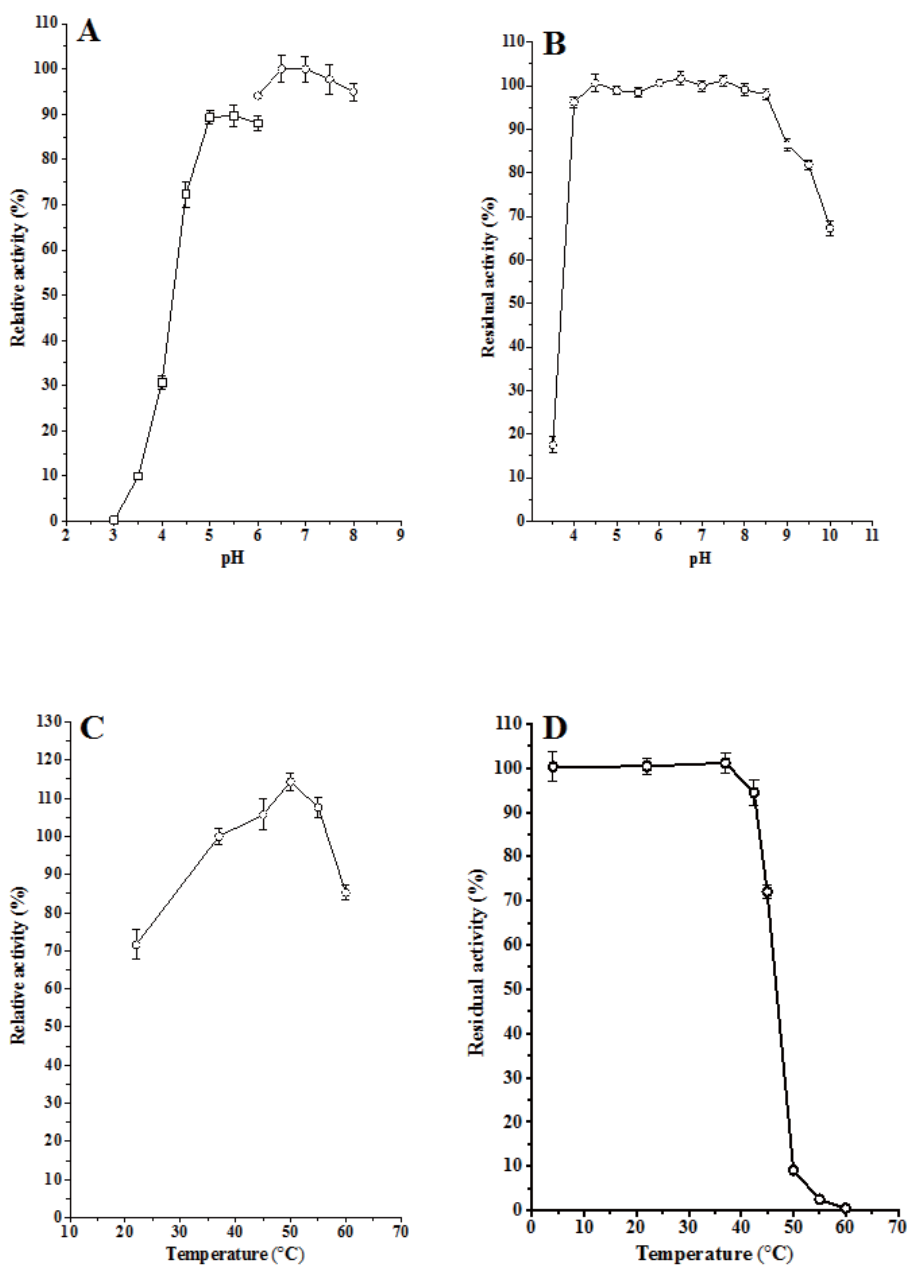

Fig. (5). Optimal pH, pH stability, optimal temperature and heat-stability of purified cysteine protease from Actinidia arguta.

(A): The purified enzyme $(0.5 \mu \mathrm{g})$ was incubated in $50 \mathrm{mM}$ citrate buffer and sodium phosphate buffer at various $\mathrm{pHs}(3.0 \sim 8.0)$ for $10 \mathrm{~min}$ at $37{ }^{\circ} \mathrm{C}$. The activity for Z-Leu-Arg-MCA was determined, and the activity obtained at pH 7.0 was useded as the standard (100\%). Each value is the mean \pm SE from triplicate experiments. ( $($ ): sodium phosphate buffer; $(\square)$ : sodium citrate buffer. (B): The purified enzyme $(0.5 \mu \mathrm{g})$ was stored in $50 \mathrm{mM}$ 
GTA buffer at various $\mathrm{pHs}(3.5 \sim 10.0)$ for $24 \mathrm{hr}$ at $4^{\circ} \mathrm{C}$, and then the activity for Z-Leu-Arg-MCA was determined. The activity obtained at pH 7.0 was used as the standard (100\%). Each value is the mean $\pm \mathrm{SE}$ from triplicate experiments. (C): The purified enzyme (0.5 $\mu \mathrm{g})$ was incubated in 50 $\mathrm{mM}$ sodium phosphate buffer, $\mathrm{pH} 7.0$, at various temperatures $\left(22 \sim 60^{\circ} \mathrm{C}\right)$ for $10 \mathrm{~min}$. The activity for Z-Leu-Arg-MCA was determined, and the activity obtained at $37^{\circ} \mathrm{C}$ was used as the standard (100\%). Each value is the mean \pm SE from triplicate experiments. (D): The purified enzyme (0.5 $\mu \mathrm{g})$ was pre-incubated in $50 \mathrm{mM}$ sodium phosphate buffer, $\mathrm{pH} 7.0$, at various temperatures $\left(22 \sim 60^{\circ} \mathrm{C}\right)$ for 10 min and then incubated for an additional $10 \mathrm{~min}$ after an addition of the substrate. The activity obtained at $22^{\circ} \mathrm{C}$ was used as the standard (100\%). Each value is the mean $\pm \mathrm{SE}$ from triplicate experiments.

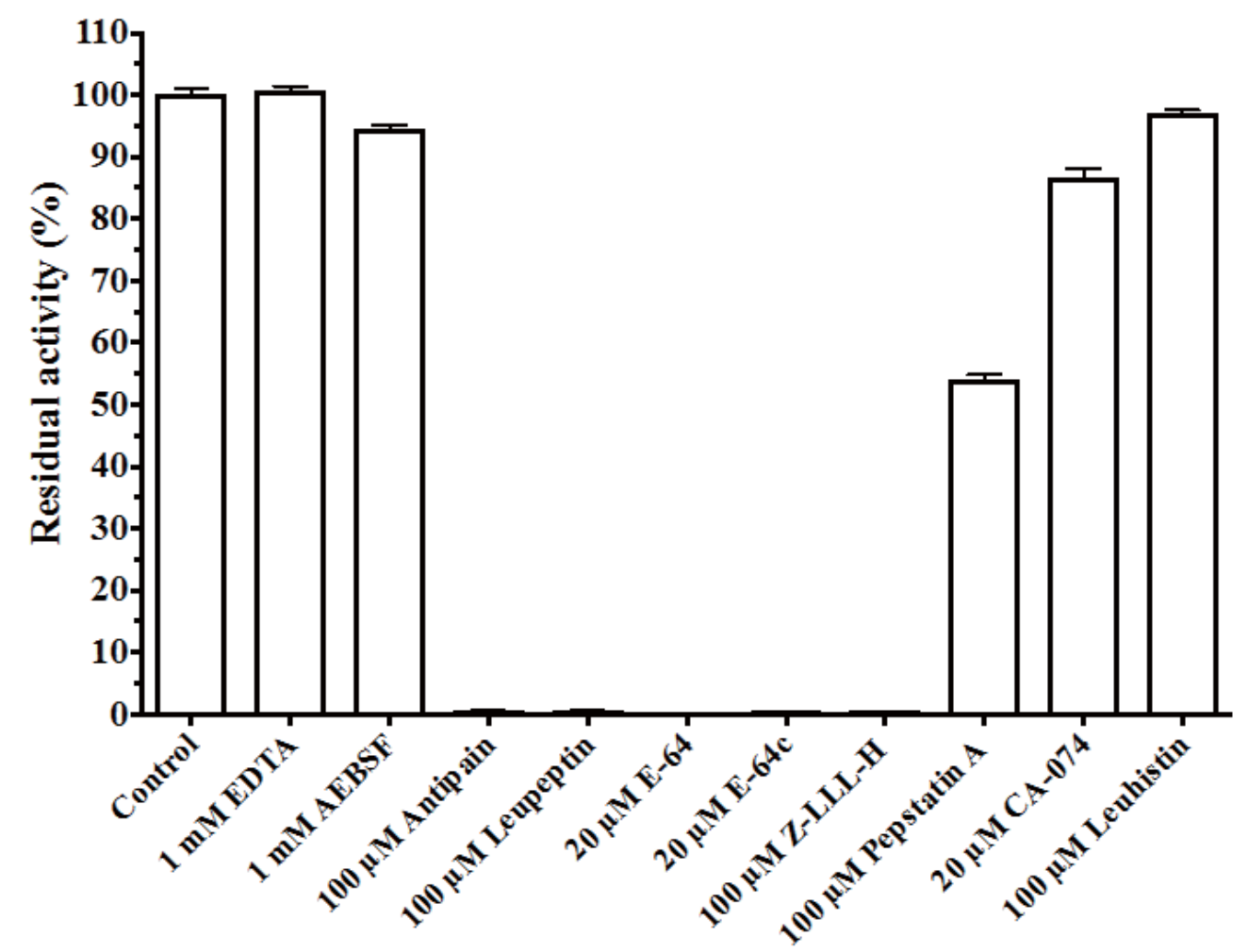

Fig. (6). Inhibition of the activity of cysteine protease from Actinidia arguta by several protease inhibitors including E-64, kinin-free low molecular weight kininogen and cysteine $\mathrm{C}$.

The purified enzyme $(0.5 \mu \mathrm{g})$ was pre-incubated with each inhibitor for $10 \mathrm{~min}$ at room temperature in $50 \mathrm{mM}$ sodium phosphate buffer, $\mathrm{pH} 7.0$, and assays were started by adding $100 \mu \mathrm{M}$ Z-Leu-Arg-MCA. The reaction mixtures were incubated for an additional 10 min at $37^{\circ} \mathrm{C}$. Each value is the mean \pm SE from triplicate experiments.

Table 3. Kinetic parameters of cysteine protease from $A$. arguta toward several substrates.

\begin{tabular}{|c|c|c|c|c|}
\hline Substrate & $\boldsymbol{K}_{\mathrm{m}}(\boldsymbol{\mu} \mathbf{M})$ & $\boldsymbol{V}_{\max }(\boldsymbol{\mu m o l e s} / \mathbf{m g} / \mathbf{m i n})$ & $\boldsymbol{K}_{\text {cat }}\left(\mathbf{s e c}^{-1}\right)$ & $\boldsymbol{K} \mathbf{c a t}^{-1} \mathbf{K m}\left(\mathbf{s e c}^{-1} \boldsymbol{\mu} \mathbf{M}^{-1}\right)$ \\
\hline Z-Leu-Arg-MCA & 100 & 63.8 & 27.26 & 0.2726 \\
\hline Z-Val-Val-Arg-MCA & 263 & 41.4 & 17.69 & 0.0672 \\
\hline Boc-Val-Leu-Lys-MCA & 91 & 41.5 & 17.74 & 0.1949 \\
\hline Z-Phe-Arg-MCA & 222 & 34.9 & 14.91 & 0.0671 \\
\hline
\end{tabular}

Table 4. $\mathrm{IC}_{50}$ values of inhibitory activity of various inhibitors toward cysteine protease purified from $A$. arguta.

\begin{tabular}{|c|c|}
\hline Inhibitor & $\mathbf{I C}_{\mathbf{5 0}}(\mathbf{n M})$ \\
\hline E-64 & 4.5 \\
\hline E-64c & 11.5 \\
\hline CA-074 & $26,500.0$ \\
\hline Leupeptin & 55.0 \\
\hline Antipain & 93.0 \\
\hline
\end{tabular}


(Table 4) contd....

\begin{tabular}{|c|c|}
\hline Iable 4) contd..... & IC $_{\mathbf{5 0}}(\mathbf{n M})$ \\
\hline Z-LLL-H & 9.0 \\
\hline Pepstatin A & 160.0 \\
\hline Kinin-free LMW kininogen & 4.6 \\
\hline Cystatin C & 30.5 \\
\hline
\end{tabular}

Actinidia arguta

Actinidia deliciosa

Actinidia eriantha

Carica papaya

Ananas comosus (Fruit)

Ananas comosus (Stem)

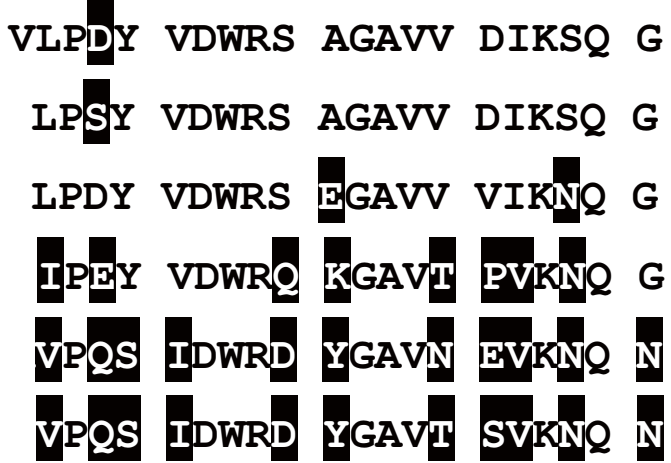

$100.0 \%$

$95.0 \%$

$90.0 \%$

$60.0 \%$

$45.0 \%$

$45.0 \%$

Fig. (7). Comparison of the $N$-terminal amino acid sequence of cysteine protease from Actinidia arguta with those of cysteine proteases from Actinidia deliciosa, Actinidia eriantha, Carica papaya and Ananas comsus (fruit and stem).

The $N$-terminal amino acid sequence of cysteine protease from Actinidia arguta is aligned against the sequences of cysteine proteases from Actinidia deliciosa (GenBank accession no. ABQ1090), Actinidia eriantha (ABQ 10191), Carica Papaya (AAB 02650) and Ananas comsus (fruit (BAA 21929) and stem (CAA 08860.1)). Non-conserved amino acid residues among the cysteine proteases of those fruits are shown in filled boxes.

The $50 \%$ inhibition $\left(\mathrm{IC}_{50}\right)$ values of inhibitory activity of various inhibitors toward cysteine protease purified from $A$. arguta were determined with a fixed substrate concentration of $100 \mu \mathrm{M}$ but with various inhibitor concentrations (Table 3).

The relative order of $\mathrm{IC}_{50}$ values of synthetic inhibitors was E-64 $>$ Z-LLL-H $>$ E64c $>$ leupetin $>$ antipain. Furthermore, two proteinase inhibitors, kinin-free LMW (low molecular weight) kininogen [28] and cystatin $\mathrm{C}$ [29], strongly inhibited the activity of the enzyme $\left(\mathrm{IC}_{50}=3.9\right.$ and $32.0 \mathrm{nM}$, respectively) [30]. LMW kininogen is well known to have three homologous copies of cystatin $\mathrm{C}$, and among the three domains, domain 2 and 3 strongly inhibit the activity of cysteine protease. Accordingly, it is thought that the difference in the $\mathrm{IC}_{50}$ values of the two inhibitors depends on their number of inhibitor domains [31 - 33] (Table 4).

\subsubsection{Comparison of the Amino Acid Sequences of Cysteine Proteases Between A. arguta and Other Plants}

As shown in Fig. (7), the amino acid sequence of the first 21 residues of cysteine protease purified from $A$. arguta was Val $^{1}$-Leu-Pro-Asp-Tyr ${ }^{5}$-Val-Asp-Trp-Arg-Ser ${ }^{10}$-Ala-Gly-AlaVal-Val $^{15}$-Asp-Ile-Lys-Ser-Qln ${ }^{20}$-Gly. However, both valine ${ }^{1}$ and leucine ${ }^{2}$ were detected with has been a 1:1 ratio as the $N$ terminal amino acid (figure not shown). On the other hand, it has been reported that the $N$-terminal amino acid of actinidin from Actinidia delisiosa and that of papain from C. papaya started at the $2^{\text {nd }}$ position (Fig. 7) $[24,34]$. It is thought that these proteases are synthesized as precursor forms and that their $N$-terminal regions are cleaved by the processing enzymes. However, the processing enzymes have not yet been identified. There is a possibility that in the case of cysteine protease from $A$. arguta fruit juice, the processing enzyme may not work sufficiently during its processing.
The primary function of endogenous cysteine proteases in plants is thought to be protection against arthropod pests, plantparasitic nematodes and herbivorous insects invading the plants $[35,36]$. Endogenous cysteine proteases are also thought to be involved in many physiologically important processes such as disease resistance, programmed cell death, germination and senescence [37 - 41].

On the other hand, cysteine proteases such as papain, bromelin, ficin, actinidin and zingibain from some fruits have been extensively and effectively utilized for production of tender meat [12 - 16, 19, 42, 43], although their characteristics including optimal $\mathrm{pH}$, optimal temperature and enzymatic kinetics for the production of tender meat have not been determined.

Montoya et al. $[44,45]$ reported that dietary actinidin from kiwifruit (A. deliciosa cv. Hayward) increased gastric digestion and gastric emptying rate of several dietary proteins in growing rats [44] and meat proteins in growing pigs [45]. Accordingly, cysteine protease from A. arguta fruit juice is also expected to have the same nutritional effects.

On the other hand, Cavic et al. [46] and Grozdanovic et al. [47] reported that active actinidin is resistant to Simulated Gastric Fluid (SGF) and Simulated Intestinal Fluid (SIF) and can influence/increase the uptake of complete actinidin molecules and other barely degraded proteins by breaking down occludin (a key epithelial tight junction transmembrane protein) in the tight junction network. These findings indicate that food allergens with intrinsic proteolytic activity can endanger the gut epithelial barrier, thus contributing to the sensitization process in food allergy pathogenesis.

Functional and processed foods that utilize the distinctive feature of cysteine protease from A. arguta fruit juice to promote protein digestion and absorption should be developed, 
and foods such as A. arguta and kiwifruit (A. deliciosa cv. Hayward) are also expected to contribute to the maintenance and improvement of human health through their proteolytic functions.

\section{LIST OF ABBREVIATIONS}

$$
\begin{aligned}
& \text { AEBSF = 4-(2-aminoethyl)-benzenesulfonyl fluoride } \\
& \text { AMC = 7-amino-4-methylcoumarin } \\
& \text { Boc- } \quad=t \text {-butyloxycarbonyl- } \\
& \boldsymbol{\beta} \text {-ME }=\beta \text {-mercaptoethanol } \\
& \text { E-64 }=N \text {-[N-(L-3-trans-carbxyran-2-carbonyl)-L-leucyl }] \text { agmatine } \\
& \text { EDTA = ethylendiaminetetraacetic acid } \\
& \text { LMW = low molecular weight } \\
& \text { MCA = 4-methyl-coumaryl-7-amide } \\
& \text { PAGE = polyacrylamide gel electrophoresis } \\
& \text { PMSF = phenylmethylsulfonyl fluoride } \\
& \text { Z- = benzyloxycarbonyl- } \\
& \text { SDS = sodium dodecyl sulfate }
\end{aligned}
$$

ETHICAL APPROVAL AND CONSENT TO PARTICIPATE

Not applicable.

\section{HUMAN AND ANIMAL RIGHTS}

No animals/humans were used for studies that are the basis of this research.

\section{CONSENT FOR PUBLICATION}

Not applicable.

\section{AVAILABILITY OF DATA AND MATERIALS}

Not applicable.

\section{FUNDING}

This work was supported in part by grants from the Tenshi College Research Foundation (to I. Ohkubo).

\section{CONFLICT OF INTEREST}

The authors declare no conflict of interest, financial or otherwise.

\section{ACKNOWLEDGEMENTS}

Declared none.

\section{REFERENCES}

[1] Nishiyama, I. Fruits of the actinidia genus. Adv. Food Nutr. Res., 2007, 52, 293-324 [http://dx.doi.org/10.1016/S1043-4526(06)52006-6] [PMID: 1742 5948]

[2] Briggs, M. Sarunashi (Actinidiaceae) of new Guinea: Current status, future plans. Gardens'. Bull Shingapore, 2011, 63, 77-82.

[3] Latocha, P. The nutritional and health benefits of kiwiberry (Actinidia arguta) -a Review. Plant Foods Hum. Nutr., 2017, 72(4), 325-334. [http://dx.doi.org/10.1007/s11130-017-0637-y] [PMID: 28988409]

[4] Zou, L-L.; Wang, Z-Y.; Fan, Z-L.; Tian, S-Q.; Liu, J-R. Evaluation of antioxidant and antiproliferative properties of three actinidia (Actinidia kolomkt, Actinidia arguta, Actinidia chinensis) extracts in vitro. Int. J. Mo.l Sci, 2012, 13, 5506-5518. [http://dx.doi.org/10.3390/ijms13055506]

[5] Cyboran, S.; Oszmiański, J.; Kleszczyńska, H. Modification of the properties of biological membrane and its protection against oxidation by Actinidia arguta leaf extract. Chem. Biol. Interact., 2014, 222, 50-59.

[http://dx.doi.org/10.1016/j.cbi.2014.08.012] [PMID: 25199699]

[6] Latocha, P.; Krupa, T.; Wołosiak, R.; Worobiej, E.; Wilczak, J. Antioxidant activity and chemical difference in fruit of different Actinidia sp. Int. J. Food Sci. Nutr., 2010, 61(4), 381-394. [http://dx.doi.org/10.3109/09637480903517788] [PMID: 20113214]

[7] Lim, S.; Han, S-H.; Kim, J.; Lee, H-J.; Lee, J-G.; Lee, E-J. Inhibition of hardy kiwifruit (Actinidia aruguta) ripening by 1methylcyclopropene during cold storage and anticancer properties of the fruit extract. Food Chem., 2016, 190, 150-157.

[http://dx.doi.org/10.1016/j.foodchem.2015.05.085] [PMID: 2621 2954]

[8] Nishimura, M.; Okimasu, Y.; Miyake, N.; Tada, M.; Hida, R.; Negishi, T.; Arimoto-Kobayashi, S. Inhibitory effect of Actinidia arguta on mutagenesis, inflammation and two-stage mouse skin tumorigenesis. Genes Environ., 2016, 38, 25-37.

[http://dx.doi.org/10.1186/s41021-016-0053-9] [PMID: 27822323]

[9] Kim, D.; Kim, S.H.; Park, E.J.; Kang, C.Y.; Cho, S.H.; Kim, S. Antiallergic effects of PG102, a water-soluble extract prepared from Actinidia arguta, in a murine ovalbumin-induced asthma model. Clin. Exp. Allergy, 2009, 39(2), 280-289.

[http://dx.doi.org/10.1111/j.1365-2222.2008.03124.x] [PMID: 1903 2361]

[10] Lee, J.; Sowndhararajan, K.; Kim, M.; Kim, J.; Kim, D.; Kim, S.; Kim, G.Y.; Kim, S.; Jhoo, J.W. Antioxidant, inhibition of $\alpha$-glucosidase and suppression of nitric oxide production in LPS-induced murine macrophages by different fractions of Actinidia arguta stem. Saudi J. Biol. Sci., 2014, 21(6), 532-538.

[http://dx.doi.org/10.1016/j.sjbs.2014.01.006] [PMID: 25473361]

[11] Nam, S.H.; Walsh, M.K.; Yang, K.Y. The enzymatic properties of actinidin from kiwi fruit. Food Sci. Biotechnol., 2006, 15, 453-457.

[12] Aminlari, M.; Shekarforoush, S.S.; Gheisari, H.R.; Golestan, L. Effect of actinidin on the protein solubility, water holding capacity, texture, electrophoretic pattern of beef, and on the quality attributes of a sausage product. J. Food Sci., 2009, 74(3), C221-C226.

[http://dx.doi.org/10.1111/j.1750-3841.2009.01087.x] [PMID: 1939 7706]

[13] Lee, D.H.; Jin, B.H. Encapsulaion of bromelin in liposome. J. Food Sci. Nutr, 2001, 5, 81-85.

[14] Kee, H.J.; Hwang, Ys.; Kim, K.H.; Hog, Y.H. Application fig protease to foods. Korean J. Food Sci. An., 1998, 18, 19-26.

[15] Brooks, B.A.; Kalsing, K.C.; Regenstein, J.M. Effects of antemortem injected crude papain in chicken muscle. J. Food Sci., 1985, 50, 1370-1375.

[http://dx.doi.org/10.1111/j.1365-2621.1985.tb10479.x]

[16] Bekhit, A.A.; Hopkins, D.L.; Geesink, G.; Bekhit, A.A.; Franks, P. Exogenous proteases for meat tenderization. Crit. Rev. Food Sci. Nutr., 2014, 54(8), 1012-1031.

[http://dx.doi.org/10.1080/10408398.2011.623247] [PMID: 24499119]

[17] Nieuwenhuizen, N.; Beuning, L.; Sutherland, P.; Sharma, N.; Cooney, J.; Bieleski, L.; Schroeder, R.; MacRae, E.; Atkinson, R. Identification and characterization of acidic and novel basic forms of actinidin, the highly abundant cysteine protease from kiwifruit. Funct. Plant Biol., 2007, 34, 946-961.

[http://dx.doi.org/10.1071/FP07121]

[18] Yogavel, M.; Nithya, N.; Suzuki, A.; Sugiyama, Y.; Yamane, T.; Velmurugan, D.; Sharma, A. Structural analysis of actinidin and a comparison of cadmium and sulfur anomalous signals from actinidin crystals measured using in-house copper- and chromium-anode X-ray sources. Acta Crystallogr. D Biol. Crystallogr., 2010, 66(Pt 12), 1323-1333.

[http://dx.doi.org/10.1107/S0907444910040394] [PMID: 21123873]

[19] Wang, J.; Liu, H.; Wang, H.; Gui, M.; Jin, Q.; Jin, T.; Cui, F.; Cui, T.; Liang, C.; Kim, B.; Li, G. Isolation and characterization of a protease from the Actinidia arguta fruit for improving meat tenderness. Food Sci. Biotechnol., 2016, 25(4), 1059-1064.

[http://dx.doi.org/10.1007/s10068-016-0171-y] [PMID: 30263375]

[20] Bradford, M.M. A rapid and sensitive method for the quantitation of microgram quantities of protein utilizing the principle of protein-dye binding. Anal. Biochem., 1976, 72, 248-254.

[http://dx.doi.org/10.1016/0003-2697(76)90527-3] [PMID: 942051]

[21] Laemmli, U.K. Cleavage of structural proteins during the assembly of 
the head of bacteriophage T4. Nature, 1970, 227(5259), 680-685. [http://dx.doi.org/10.1038/227680a0] [PMID: 5432063]

[22] Ozawa, K.; Ohnishi, T.; Tanaka, S. Activation and inhibition of papain. J. Biochem., 1962, 51, 372-374. [PMID: 14482961]

[23] Sanner, T.; Pihl, A. Studies on the active--SH group of papain and on the mechanism of papain activation by thiols. J. Biol. Chem., 1963, 238, 165-171.

[PMID: 13976329]

[24] Carne, A.; Moore, C.H. The amino acid sequence of the tryptic peptides from actinidin, a proteolytic enzyme from the fruit of Actinidia chinensis. Biochem. J., 1978, 173(1), 73-83. [http://dx.doi.org/10.1042/bj1730073] [PMID: 687380]

[25] Roberta, L.P-I.P.; Petrone, G. Characterization of the purified actinidin as a coagulant of bovine milk. Eur. Food Res. Technol., 2011, 233, 517-524.

[http://dx.doi.org/10.1007/s00217-011-1543-4]

[26] Theodorou, L.G.; Bieth, J.G.; Papamichael, E.M. The catalytic mode of cysteine proteinases of papain (C1) family. Bioresour. Technol., 2007, 98(10), 1931-1939.

[http://dx.doi.org/10.1016/j.biortech.2006.07.037] [PMID: 16997546]

[27] Gagaoua, M.; Boucherba, N.; Bouanane-Darenfed, A.; Ziane, F.; NaitRabah, S.; Hafid, K.; Boudechicha, H. Three-phase partitioning as an efficient method for the purification and recovery of ficin from Mediterranean fig (Ficus carica L.) latex. Separ. Purif. Tech., 2014, 132, 461-467.

[http://dx.doi.org/10.1016/j.seppur.2014.05.050]

[28] Ohkubo, I.; Kurachi, K.; Takasawa, T.; Shiokawa, H.; Sasaki, M. Isolation of a human cDNA for $\alpha_{2}$-thiol proteinase inhibitor and its identity with low molecular weight kininogen. Biochemistry, 1984, 23(24), 5691-5697.

[http://dx.doi.org/10.1021/bi00319a005] [PMID: 6441591]

[29] Ishiguro, H.; Ohkubo, I.; Mizokami, M.; Titani, K.; Sasaki, M. The use of monoclonal antibodies to define levels of cystatin $\mathrm{C}$ in normal human serum. Hybridoma, 1989, 8(3), 303-313.

[http://dx.doi.org/10.1089/hyb.1989.8.303] [PMID: 2744786]

[30] Lindahl, P.; Abrahamson, M.; Björk, I. Interaction of recombinant human cystatin $\mathrm{C}$ with the cysteine proteinases papain and actinidin. Biochem. J., 1992, 281(Pt 1), 49-55.

[http://dx.doi.org/10.1042/bj2810049] [PMID: 1731767]

[31] Salvesen, G.; Parkes, C.; Abrahamson, M.; Grubb, A.; Barrett, A.J. Human low- $M_{\mathrm{r}}$ kininogen contains three copies of a cystatin sequence that are divergent in structure and in inhibitory activity for cysteine proteinases. Biochem. J., 1986, 234(2), 429-434. [http://dx.doi.org/10.1042/bj2340429] [PMID: 3521586]

[32] Machleidt, W.; Thiele, U.; Laber, B.; Assfalg-Machleidt, I.; Esterl, A.; Wiegand, G.; Kos, J.; Turk, V.; Bode, W. Mechanism of inhibition of papain by chicken egg white cystatin. Inhibition constants of $\mathrm{N}$ terminally truncated forms and cyanogen bromide fragments of the inhibitor. FEBS Lett., 1989, 243(2), 234-238. [http://dx.doi.org/10.1016/0014-5793(89)80135-8] [PMID: 2917648]

[33] Auerswald, EA.; Nägler, DK.; Gross, S.; Assfalg-Machleidt, I.; Stubbs, M.T.; Eckerskorn, C.; Machleidt, W.; Fritz, H. Hybrids of chicken cystatin with human kininogen domain 2 sequences exhibit novel inhibition of calpain, improved inhibition of actinidin and impaired inhibition of papain, cathepsin L and cathepsin B. Eur. J. Biochem., 1996, 235(3), 534-542.

[http://dx.doi.org/10.1111/j.1432-1033.1996.00534.x] [PMID: 8654 398]

[34] Lee, K.L.; Albee, K.L.; Bernasconi, R.J.; Edmunds, T. Complete amino acid sequence of ananain and a comparison with stem bromelain and other plant cysteine proteases. Biochem. J., 1997, 327(Pt 1), 199-202.

[http://dx.doi.org/10.1042/bj3270199] [PMID: 9355753]
[35] Shindo, T.; Van der Hoorn, R.A.L. Papain-like cysteine proteases: key players at molecular battlefields employed by both plants and their invaders. Mol. Plant Pathol., 2008, 9(1), 119-125. [PMID: 18705889]

[36] Konno, K.; Hirayama, C.; Nakamura, M.; Tateishi, K.; Tamura, Y.; Hattori, M.; Kohno, K. Papain protects papaya trees from herbivorous insects: role of cysteine proteases in latex. Plant J., 2004, 37(3), 370-378.

[http://dx.doi.org/10.1046/j.1365-313X.2003.01968.x] [PMID: 1473 1257]

[37] Gilroy, E.M.; Hein, I.; van der Hoorn, R.; Boevink, P.C.; Venter, E.; McLellan, H.; Kaffarnik, F.; Hrubikova, K.; Shaw, J.; Holeva, M.; López, E.C.; Borras-Hidalgo, O.; Pritchard, L.; Loake, G.J.; Lacomme, C.; Birch, P.R.J. Involvement of cathepsin B in the plant disease resistance hypersensitive response. Plant J., 2007, 52(1), 1-13. [http://dx.doi.org/10.1111/j.1365-313X.2007.03226.x] [PMID: 1769 7096]

[38] Sueldo, D.J.; van der Hoorn, R.A.L. Plant life needs cell death, but does plant cell death need Cys proteases? FEBS J., 2017, 284(10), 1577-1585.

[http://dx.doi.org/10.1111/febs.14034] [PMID: 28165668]

[39] Tsuji, A.; Tsukamoto, K.; Iwamoto, K.; Ito, Y.; Yuasa, K. Enzymatic characterization of germination-specific cysteine protease-1 expressed transiently in cotyledons during the early phase of germination. $J$. Biochem., 2013, 153(1), 73-83.

[http://dx.doi.org/10.1093/jb/mvs125] [PMID: 23112094]

[40] Szewińska, J.; Simińska, J.; Bielawski, W. The roles of cysteine proteases and phytocystatins in development and germination of cereal seeds. J. Plant Physiol., 2016, 207, 10-21.

[http://dx.doi.org/10.1016/j.jplph.2016.09.008] [PMID: 27771502]

[41] Díaz-Mendoza, M.; Velasco-Arroyo, B.; González-Melendi, P.; Martínez, M.; Díaz, I. C1A cysteine protease-cystatin interactions in leaf senescence. J. Exp. Bot., 2014, 65(14), 3825-3833. [http://dx.doi.org/10.1093/jxb/eru043] [PMID: 24600023]

[42] Ha, M.; Bekhit, A.; Carne, A.; Hopkins, D.L. Characterization of commercial papain, bromelin, actinidin and zingibain protease preparations and their activities toward meat proteins. Food Chem., 2012, 134, 95-105.

[http://dx.doi.org/10.1016/j.foodchem.2012.02.071]

[43] Naveena, B.M.; Mendiratta, S.K. Tenderisation of spent hen meat using ginger extract. Br. Poult. Sci., 2001, 42(3), 344-349. [http://dx.doi.org/10.1080/00071660120055313] [PMID: 11469554]

[44] Montoya, C.A.; Rutherfurd, S.M.; Olson, T.D.; Purba, A.S.; Drummond, L.N.; Boland, M.J.; Moughan, P.J. Actinidin from kiwifruit (Actinidia deliciosa cv. Hayward) increases the digestion and rate of gastric emptying of meat proteins in the growing pig. $\mathrm{Br}$. $J$. Nutr., 2014, 111(6), 957-967.

[http://dx.doi.org/10.1017/S0007114513003401] [PMID: 24252432]

[45] Montoya, C.A.; Hindmarsh, J.P.; Gonzalez, L.; Boland, M.J.; Moughan, P.J.; Rutherfurd, S.M. Dietary actinidin from kiwifruit (Actinidia deliciosa cv. Hayward) increases gastric digestion and the gastric emptying rate of several dietary proteins in growing rats. $J$. Nutr., 2014, 144(4), 440-446.

[http://dx.doi.org/10.3945/jn.113.185744] [PMID: 24431326]

[46] Cavic, M.; Grozdanovic, M.M.; Bajic, A.; Jankovic, R.; Andjus, P.R.; Gavrovic-Jankulovic, M. The effect of kiwifruit (Actinidia deliciosa) cysteine protease actinidin on the occludin tight junction network in T84 intestinal epithelial cells. Food Chem. Toxicol., 2014, 72, 61-68. [http://dx.doi.org/10.1016/j.fct.2014.07.012] [PMID: 25042511]

[47] Grozdanovic, M.M.; Ostojic, S.; Aleksic, I.; Andjelkovic, U.; Petersen, A.; Gavrovic-Jankulovic, M. Active actinidin retains function upon gastro-intestinal digestion and is more thermostable than the E-64inhibited counterpart. J. Sci. Food Agric., 2014, 94(14), 3046-3052. [http://dx.doi.org/10.1002/jsfa.6656] [PMID: 24633720]

\section{C) 2019 Miyazaki-Katamura et al.}

This is an open access article distributed under the terms of the Creative Commons Attribution 4.0 International Public License (CC-BY 4.0), a copy of which is available at: https://creativecommons.org/licenses/by/4.0/legalcode. This license permits unrestricted use, distribution, and reproduction in any medium, provided the original author and source are credited. 